\title{
Growth Variation of Swietenia macrophylla King. Progeny Trial at 18 Months of Age in Trenggalek East Java
}

\author{
Mashudi $^{1} *$ Sugeng Pudjiono ${ }^{1}$ Dedi Setiadi ${ }^{1}$ Nur Hidayati $^{2}$ Maman Sulaeman $^{3}$ \\ Liliana Baskorowati ${ }^{4}$ Rina Laksmi Hendrati ${ }^{4}$ Mudji Susanto ${ }^{4}$
}

\author{
${ }^{I}$ Senior reseacher, Centre for Forest Biotechnology and Tree Improvement \\ ${ }^{2}$ Junior reseacher, Centre for Forest Biotechnology and Tree Improvement \\ ${ }^{3}$ Technician, Centre for Forest Biotechnology and Tree Improvement \\ ${ }^{4}$ Professor research, Centre for Forest Biotechnology and Tree Improvement \\ *Corresponding author. Email: masshudy@yahoo.com
}

\begin{abstract}
Swietenia macrophylla King. as known as wide leaf mahogany is a type of exotic species from Latin America that is common planted in Indonesia. This species is widely cultivated in several regions in Indonesia due to the high demand for carpentry timber. Therefore, to meet the high demand of wide leaf mahogany wood, the development of plantation forests of S. macrophylla with high productivity is very much needed. Development of plantation forests with high productivity requires the support of improvement seeds. Therefore, this study was conducted to determine the survival rate, growth variation between land race and between mother trees of 18 months old of S. macrophylla progeny trial. This progeny trial at the end of the selection can be converted into a seedling seed orchard (SSO) to produce the improvement seeds. Incomplete Block Design with two factors, i.e. land race (5 levels) and mother tree (50 levels) was used in this study. The results of the analysis showed that the survival rates of plant was significantly different between the land race but not among the mother trees. The average of survival rate of this species is only $71.58 \%$, due to the landslide during the rainy season, burnt during the dry season and also exposed to stem borer attacks. Growth parameters (height and stem diameter) were significantly different between land race and mother tree. It showed that the Bondowoso land race exhibited the best performance of height and stem diameter, respectively $151.55 \mathrm{~cm}$ and $21.97 \mathrm{~mm}$. The best mother tree in terms of growth (height and stem diameter) were exhibited on 19 individual tresses, with a range from 130.38 to $171.64 \mathrm{~cm}$ for height character and from 20.46 to $26.47 \mathrm{~mm}$ for stem diameter character.
\end{abstract}

Keywords: growth variation, progeny trial, land race, mother tree, Swietenia macrophylla

\section{INTRODUCTION}

Wide leaf mahogany (Swietenia macrophylla King.) is an important timber-producing species in Indonesia. Mahogany timber generally used for several purposes including as construction materials, plywood (plywood / veneer), furniture, panels, frames, floors, car body, boat interior and molding [1]. The high economic value of mahogany caused increasing the development of mahogany plantations; especially the local people in several regions including Java, South Kalimantan and Nusa Tenggara tend to plant this species due to high demand of the timber [2]. To support the development of plantations of $S$. macrophylla with high productivity, the availability of improvement seeds is very important.

S. macrophylla is an introduced species planted by the Dutch since the 1890s [2]. It was further conveyed that, natural habitats of this species are in Latin America. Although it is an introduced species, this species has a high genetic diversity [3,4]. In term of tree breeding, high genetic diversity is very important; it means that having high diversity will lead the opportunity for having a superior tree by selection. At the end of the selection of selected trees in the progeny trial can be converted into seed 
orchard. In this study the S. macrophylla progeny trial was established in Trenggalek, East Java. The seed source of the progeny trial comes from 5 land races, collected from Banjar-West Java, DlingoBantul, Samigaluh-Kulonprogo, Bon-dowoso-East Java, and Lombok-West Nusa Tenggara [5]. Periodic measurements every 6 months of survival rate, height and stem diameter were undertaken to determine the diversity of plant growth. Those data were analyzed as a basic information for the implementation of the selection. Therefore, this study was conducted to find out the survival rate, growth variation between land races and between mother trees of $S$. macrophylla progeny trial at 18 months of age.

\section{MATERIALS AND METHODS}

\subsection{Location}

The research was carried out on the $S$. macrophylla progeny trial in Dompyong Village, Bendungan District, Trenggalek Regency, East Java Province in June 2018. The study site located $729 \mathrm{~m}$ above sea level, latitude $7^{\circ} 55,483^{\prime}$ LS and longitude $111^{\circ} 43,221^{\prime}$ BT. The soil type of study site is Litosol and the amount of rainfall in 2017 was $5,083 \mathrm{~mm}$ [6].

\subsection{Materials}

The research was conducted at 18 months old of S. macrophylla progeny test, consisting of fifty mother trees from five land races. The seed from Banjar-West Java of 15 mother trees; Dlingo-Bantul of 7 mother trees; Samigaluh-Kulonprogo of 10 mother trees, Bondowoso-East Java of 2 mother trees and Lombok-West Nusa Tenggara of 16 mother trees [5]. The geographical location and altitude of the 5 land races are presented in Table 1. another material used is a tally sheet to record the measurement. Then the instrument used in this study is a pole meter to measure the plant height and calipers to measure the stem diameter. The height and the stem diameter were measured with the sampling intensity of $100 \%$. The height of the plant was assessed by measuring the base of the stem to the top of the plant, and the diameter of the stem by measuring at a height of \pm 5 $\mathrm{cm}$ from the ground surface. To simplify the measurement, tally sheets are printed and arranged according to plant design.

\subsection{Design and Data Analysis}

The Incomplete Block Design (IBD) with 2 factors, namely land race and mother tree were used for this research due to the site location has a high slope. The mother tree (nested) in the land race in this study. Land race factor consists of 5 levels and the mother tree factor consists of 50 levels. Each mother tree consisting of 3 tree plots and 6 blocks as replication with a spacing of $4 \times 2$ meter. In the field, tree plot planting follows the contour direction at a distance of 2 meter between plants. To determine diversity, the data were analyzed for variance using the following model [7] :

$$
\begin{gathered}
Y_{i j k l m}=\mu+B_{i}+R_{j}\left(B_{i}\right)+C_{k}\left(B_{i}\right)+P_{l}+F_{m}\left(P_{l}\right) \\
+B_{i} * F_{m}\left(P_{l}\right)+\varepsilon_{i j k l m}
\end{gathered}
$$

Where:

$\mathrm{Y}_{i j k l m}$ : observation of the $\mathrm{i}^{\text {th }}$ block, the $\mathrm{j}^{\text {th }}$ row nested in the $\mathrm{i}^{\text {th }}$ block, the $\mathrm{k}^{\text {th }}$ column nested in the $\mathrm{i}^{\text {th }}$ block, the $1^{\text {th }}$ land race and the $\mathrm{m}^{\text {th }}$ mother tree nested in the $1^{\text {th }}$ land race;

$\mu \quad$ : average of the general observations;

$\mathrm{B}_{i} \quad$ : effect of the $\mathrm{i}^{\text {th }}$ block;

$\mathrm{R}_{j}\left(\mathrm{~B}_{i}\right) \quad$ : effect of the $\mathrm{j}^{\text {th }}$ row nested in the $\mathrm{i}^{\text {th }}$ lock;

$\mathrm{C}_{k}\left(\mathrm{~B}_{i}\right) \quad$ : effect of the $\mathrm{k}^{\text {th }}$ column nested in the $\mathrm{i}^{\text {th }}$ block;

$\mathrm{P}_{l} \quad:$ effect of the $\mathrm{I}^{\text {th }}$ land race;

$\mathrm{F}_{m}\left(\mathrm{P}_{l}\right) \quad$ : effect of the $\mathrm{m}^{\text {th }}$ mother tree nested in the $1^{\text {th }}$ land race;

$\mathrm{B}_{i} * \mathrm{~F}_{m} \quad$ : effect of the interaction between the $\mathrm{i}^{\text {th }}$

$\left(\mathrm{P}_{l}\right) \quad$ block with the $\mathrm{m}^{\text {th }}$ mother tree nested in the $1^{\text {th }}$ land race;

$\varepsilon_{i j k l m} \quad$ : random residual error.

Duncan Multiple Range Test (DMRT) will be undertaken to determine the differences in each treatment if the results of analysis of variance showed significant differences at the maximum test level of $5 \%$.

\section{RESULT AND DISCUSSION}

\subsection{Survival Rate}

The survival rate acknowledged as one factor reflecting the adaptability of plants at a new location. At 18 months old, the percentage of S. macrophylla survival rate among land races were from 66.00 to $80.56 \%$ (average $71.58 \%$ ) and the percent survival rate inter-mother tree showed from 38.89 to 88.89 (average $71.58 \%$ ). [5] revealed that the average of survival rate of 6-months-old of $S$. macrophylla was $84.44 \%$, therefore the survival rate of 18 -months-old decreased significantly. Reducing the survival rate on this progeny trial due to loss of several plants caused by landslides during the rainy season, fire during the 
dry season. Moreover, in the study site it was found that several plants damaged by stem borer attacks, attacking the base of the stem caused plant un-able to survive. Stem borers was also reported damage on the 1-year-old of $S$. macrophylla progeny trial in Kemampo, Banyuasin, South Sumatra [9]. According to $[10,11,12]$ young $S$. macrophylla plants were very susceptible to stem borer attack of Hypsipyla spp. High attack of Hypsipyla stem borer pests also reported in the provenan trial and progeny trial of $S$. macrophylla in Peninsula, Mexico [13]. Furthermore, to determine the variation between treatments, an analysis of variance was performed with the results presented in Table 2 .

The analysis of variance (Table 2) shows that the survival rate among land race was differ significantly; while the percent of survival rate between mother trees did not differ significantly. The results of the analysis of variance in this study differed from the results of the study of [5] on plants aged 6-months in the same trial plot. This phenomenon can be understood because the Table 1. Latitude and altitude of $S$. macrophylla seed sources measurement of plants is still very young, therefore the growth will increase concordance with the age. To determine the effect of land race on survial rates, the DMRT was carried out as present in Figure 1.

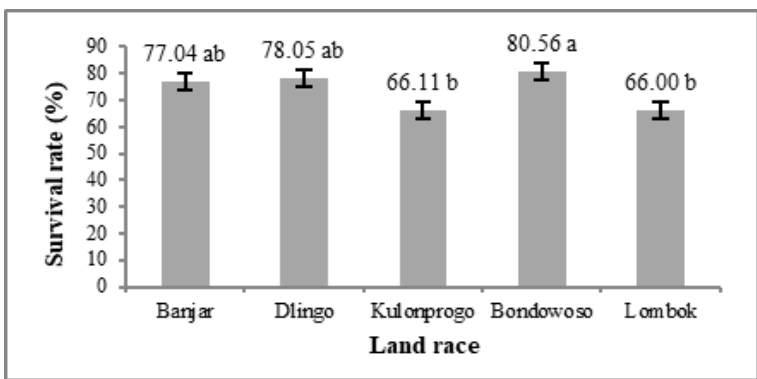

Remarks : The numbers following by the same leters were not significantly different at the 0.05 level.

Figure 1. Survival rates between land race of $S$. macrophylla progeny trial at 18 months of age

\begin{tabular}{cllll}
\hline No. & Land race & Province & Longitude and latitude & Altitude (m asl) \\
\hline 1 & Banjar, Ciamis & West Jawa & $007^{\circ} 21,144^{\prime}-007^{\circ} 30,026^{\prime} \mathrm{SL}$ & $75-250$ \\
& & & $108^{\circ} 29,393^{\prime}-108^{\circ} 39,667^{\prime} \mathrm{EL}$ & \\
2 & \multirow{2}{*}{ Dlingo, Bantul } & Special Region of & $007^{\circ} 55,225^{\prime}-007^{\circ} 56,00^{\prime} \mathrm{SL}$ & $250-380$ \\
& & Yogyakarta & $110^{\circ} 24,650^{\prime}-110^{\circ} 25,251^{\prime} \mathrm{EL}$ & \\
3 & Samigaluh, & Special Region of & $007^{\circ} 40,217^{\prime}-007^{\circ} 41,155^{\prime} \mathrm{SL}$ & $400-500$ \\
& Kulonprogo & Yogyakarta & $110^{\circ} 07,417^{\prime}-110^{\circ} 08,100^{\prime} \mathrm{EL}$ & \\
4 & Bondowoso & East Jawa & $007^{\circ} 50,315^{\prime}-007^{\circ} 59,448 \mathrm{SL}$ & $700-800$ \\
& & & $113^{\circ} 48,217^{\prime}-113^{\circ} 59,671^{\prime} \mathrm{EL}$ & \\
\multirow{2}{*}{5} & Lombok & West Nusa Tenggara & $008^{\circ} 31,913^{\prime}-008^{\circ} 40,835^{\prime} \mathrm{SL}$ & $250-500$ \\
& & $116^{\circ} 14,311^{\prime}-116^{\circ} 23,718^{\prime} \mathrm{EL}$ & \\
\hline
\end{tabular}

References Sources : $[4,8]$.

Table 2. Variace analysis of survival rate of $S$. macrophylla progeny trial at 18 months old in Trenggalek, East Java

\begin{tabular}{lccccc}
\hline Source of variation & $\begin{array}{c}\text { Degree of } \\
\text { freedom }\end{array}$ & $\begin{array}{c}\text { Sum of } \\
\text { square }\end{array}$ & Mean square & F value & Pr $>$ F \\
\hline Block & 5 & 20419.7476 & 4083.9495 & 6.17 & $<0.0001$ \\
Row (Block) & 54 & 86145.7080 & 1595.2909 & 2.41 & $<0.0001$ \\
Colom (Block) & 24 & 28460.3970 & 1185.8499 & 1.79 & 0.0180 \\
Land race & 4 & 9927.2068 & 2481.8017 & $3.75^{*}$ & 0.0060 \\
Mother tree (Land race) & 45 & 28662.7273 & 636.9495 & $0.96 \mathrm{~ns}$ & 0.5460 \\
Error & 166 & 109888.9656 & 661.9817 & & \\
Total & 298 & 283504.7523 & & & \\
\hline Remarks: * significantly different at the 0.05 level.ns= not significant at the 0.00 level
\end{tabular}


The DMRT results (Figure 1) showed that the three land races with the best survival rate were Bondowoso, Dlingo, and Banjar respectively, while the land races of Lombok and Kulonprogo have lower survival rates. This result indicated that at a young age the $S$. macrophylla plants from the Lombok and Kulonprogo land races were more susceptible to death due to pest attacks compared to other land races; it also showed that the ability to survive at the new environmental conditions of those land races were less than others.

\subsection{Growth Variation}

The analysis showed that the growth (height and stem diameter) of S. macrophylla at 18 months old were quite varied. Height between mother trees ranged from 84.40 to $171.64 \mathrm{~cm}$ (an average of $126.79 \pm 42.91 \mathrm{~cm})$ and stem diameter between the m.other trees ranged from 12.20 to $26.47 \mathrm{~mm}$ (an average of $19,15 \pm 6.22 \mathrm{~mm})$. To find out the diversity between land races and mother trees, an analysis of variance was performed with the results presented in Table 3.

Table 3. Variance analysis of growth (height and stem diameter) of S. macrophylla progeny trial at 18 months of age in Trenggalek, East Java

\begin{tabular}{lcrr}
\hline \multicolumn{1}{c}{ Source of Variation } & $\begin{array}{c}\text { Degree of } \\
\text { Freedom }\end{array}$ & Height & Stem Diameter \\
\cline { 3 - 4 } & 5 & 45021.4026 & 2037.4793 \\
Block & 54 & 6927.4937 & 175.6592 \\
Row (Block) & 24 & 10987.9192 & 227.2536 \\
Col (Block) & 4 & $16071.1608^{* *}$ & $222.2490^{* *}$ \\
Land Race & 46 & $5313.1919^{* *}$ & $111.5582^{* *}$ \\
Mother Tree (Land Race) & 147 & $2993.3886^{* *}$ & $71.1474^{* *}$ \\
Block*Mother $\quad$ Tree $\quad$ (Land & & & 38.7086 \\
Race) & 366 & 1841.334 & \\
Error & 646 & & \\
Total & Remarks: $* *$ significantly different at the 0.01 level &
\end{tabular}

Growth (height and stem diameter) of 18-monthsold $S$. macrophylla varied significantly between land races, mother trees and the interaction of replication (block) and mother trees (Table 3). Variation of growth between land races and mother trees commonly occurs in several woody plant due to the adaptability of species to the new environment; it also occurs when the seedlings were 5-months-old [4]. The diversity among land races had been reported by [3] on S. macrophylla from Central Java and East Java using isozyme markers; it has a proportion of diversity among land races of $23 \%$ and within the land race of $77 \%$. [14, 15 and 16] also informed that land race influenced the growth of S. macrophylla seedlings/plants. Significant influence of the interaction of the mother tree*block (land race) on the growth of S. macrophylla might occurred due to the progeny trial location were not homogeny in terms of the level pest and diseases, slope and soil nutrient. Duncan test on the diversity of height and stem diameter growth between land races are presented in Figure 2, while the diversity of height growth and stem diameter between mother trees are presented in Figure $3 a$ and Figure $3 b$.
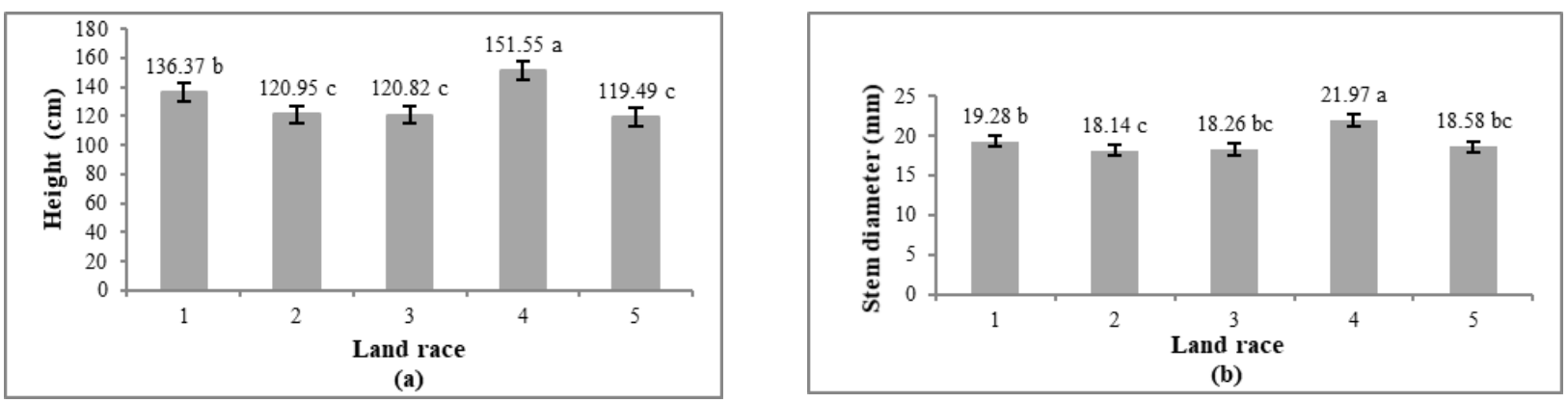

Remarks: 1 = Banjar; 2 = Dlingo; 3 = Kulonprogo; $4=$ Bondowoso and $5=$ Lombok

The numbers followed by the same letters were not significantly different at the 0.01 level.

Figure 2. DMRT of height (a) and stem diameter (b) between land race of S. macrophylla progeny trial at18 months of age 


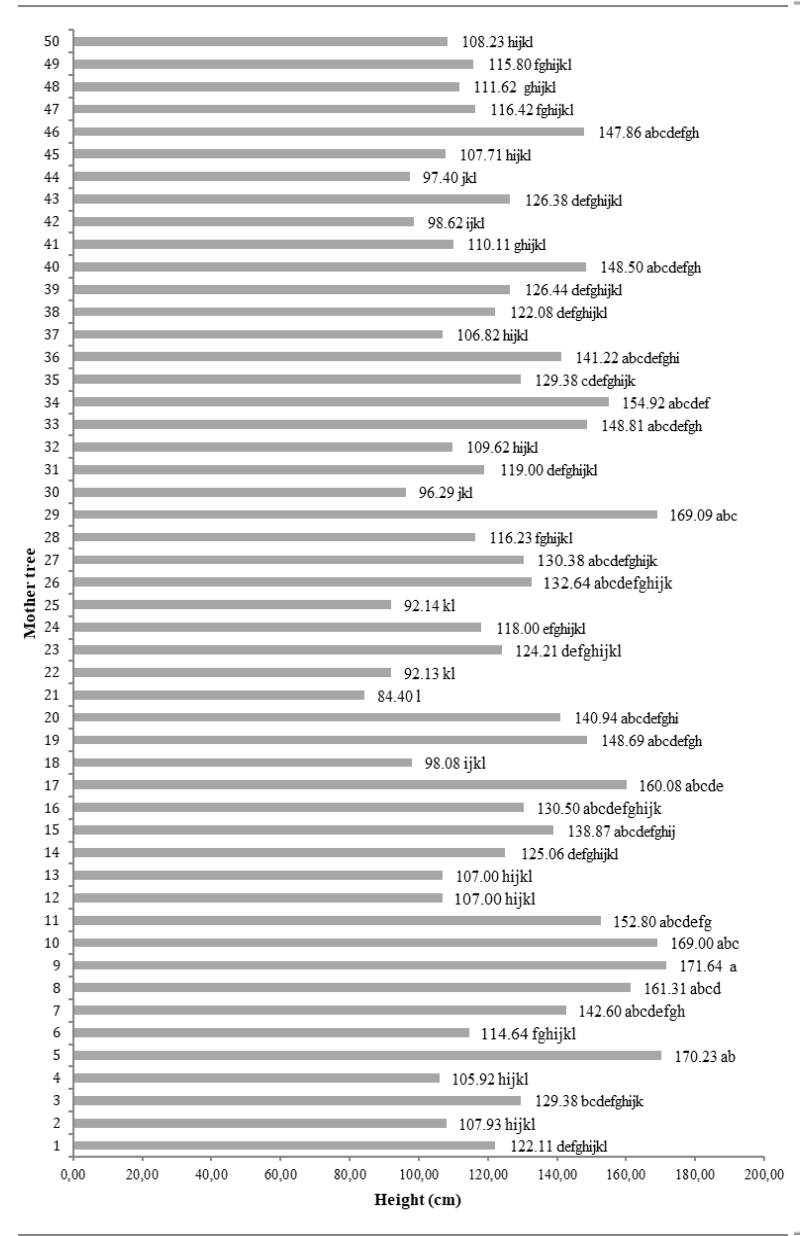

A

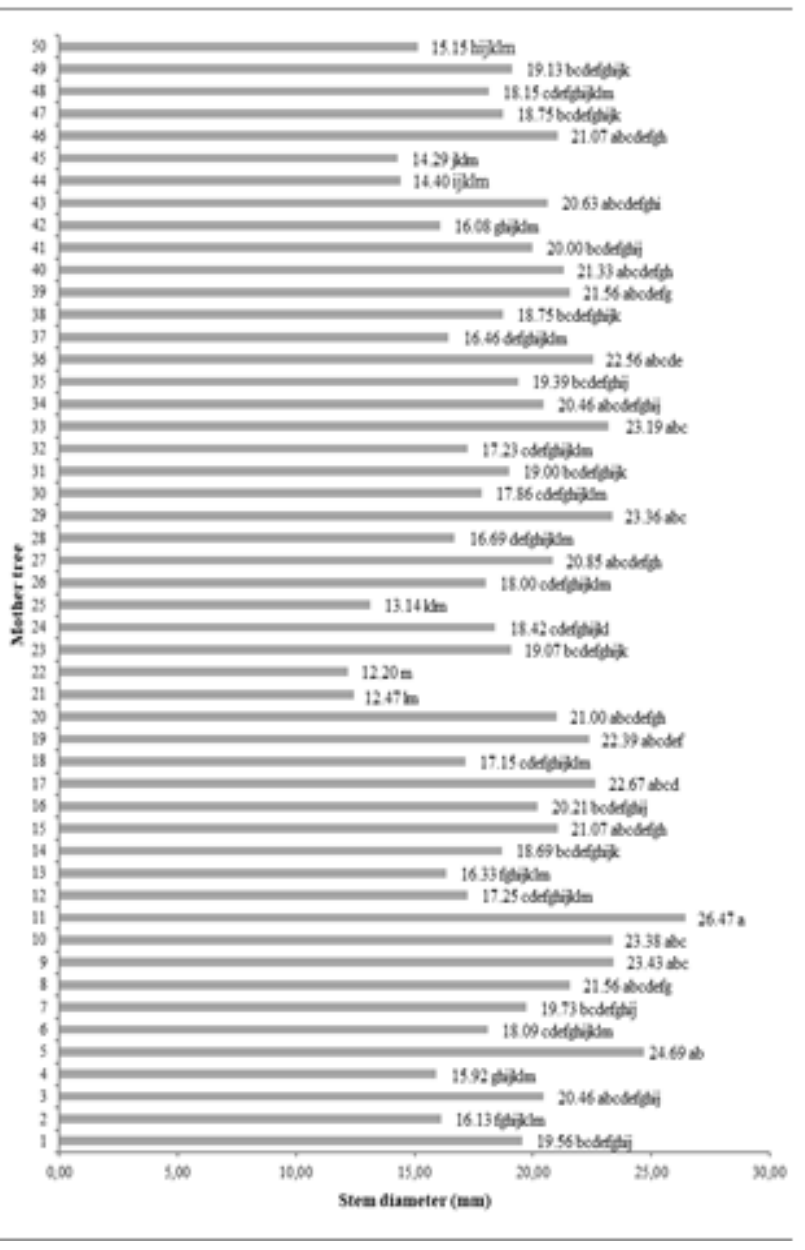

B

Remarks: The numbers followed by the same letters were not significantly different at the 0.01 level

Figure 3. DMRT of: A. Height and B. Stem diameter between mother trees of S. macrophylla progeny trial at 18 months of age.

The average of growth (height and stem diameter) S. macrophylla from Bondowoso land race exhibited the best growth compared to plants from other land races (Figure 2). Greater growth of mahogany from Bondowoso land race might due to the same elevation of progeny trial site in Trenggalek (Table 1 ), so the growth of Bondowoso land race plants is more optimum compared to other land races. [17] reported that the elevation difference will interfere with plant physiology activities which affecting plant growth. Previous study of Alstonia angustiloba progeny trial, showed that elevation differences also significantly affect plant growth among populations at 1 year old in Wonogiri, Central Java [18]. Diversity of growth between seed sources (land race) also occurs in $S$. macrophylla progeny trial at two In order to determine the growth diversity among the mother trees of $S$. macrophylla at this progeny trial, the Duncan test of height determined that mother tress separated in 12 groups (Figure 3a) and the Duncan test of stem diameters separated in 13 groups (Figure 3b). The best growth (height and stem diameter) was determined at 19 mother trees, with the range from 130.38 to $171.64 \mathrm{~cm}$ and from 20.46 to $26.47 \mathrm{~mm}$ respectively (Figure $3 \mathrm{a}$ and Figure $3 \mathrm{~b}$ ). The results of the study at 6-months-old were informed that the height growth of S. macrophylla progeny trial were grouped in 14 groups and stem diameters clustered in 13 groups [5]. This phenomenon shows that the diversity of plant height has decreased. This happens due to high mortality of trees during interval of 6 to 18 months-old, so that the diversity of plant height has decreased. Decrease in growth diversity due to the large number of plants mortality also occurred in the 2-year-old progeny trial of Alstonia angustiloba in Wonogiri, Central Java [19]. However, this research was carried out on very young plants, so the diversity of growth 
in height and stem diameter is still very likely to change. locations in Northern Mindano, Philippines [20].

In order to determine the growth diversity among the mother trees of $S$. macrophylla at this progeny trial, the Duncan test of height determined that mother tress separated in 12 groups (Figure 3a) and the Duncan test of stem diameters separated in 13 groups (Figure $3 \mathrm{~b}$ ). The best growth (height and stem diameter) was determined at 19 mother trees, with the range from 130.38 to $171.64 \mathrm{~cm}$ and from 20.46 to $26.47 \mathrm{~mm}$ respectively (Figure $3 \mathrm{a}$ and Figure $3 \mathrm{~b}$ ). The results of the study at 6-months-old were informed that the height growth of S. macrophylla progeny trial were grouped in 14 groups and stem diameters clustered in 13 groups [5]. This phenomenon shows that the diversity of plant height has decreased. This happens due to high mortality of trees during interval of 6 to 18 months-old, so that the diversity of plant height has decreased. Decrease in growth diversity due to the large number of plants mortality also occurred in the 2-year-old progeny trial of Alstonia angustiloba in Wonogiri, Central Java [19]. However, this research was carried out on very young plants, so the diversity of growth in height and stem diameter is still very likely to change.

\section{CONCLUSION}

The mortality of 18-months-old of S. macrophylla is quite high due to the landslide during the rainy season, burnt during the dry season and also exposed to stem borer attacks. Survival rate of plant is significantly affected by land race, while the mother tree has no significant effect on the survival rate of plant.

Land race and mother tree have a very significant effect on the growth of the height and the stem diameter of $S$. macrophylla progeny trial at 18 months of age. The interaction of the block with the mother tree also has a very significant effect on the growth of the height and the stem diameter of $S$. macrophylla progeny trial at 18 months of age.

\section{ACKNOWLEDGMENT}

We would like to thank to the Center for Forest Biotechnology and Tree Improvement (CFBTI) Yogyakarta under Forest Research and Development Agency (FORDA), Ministry of Environment and Forestry of the Republic Indonesia for supporting and funding this research.

\section{REFERENCES}

[1] Mashudi, H.A. Adinugraha, D. Setiadi, et al., Keragaman fenotipik buah dan daya berkecambah benih Swietenia macrophylla King. dari beberapa populasi di Indonesia, Jurnal Ilmu Kehutanan 11(2) (2017) 196-204. [In Bahasa Indonesia]

[2] H. Krisnawati, M. Kallio, M. Kanninen, Swietenia macrophylla King "Ecology, silviculture and productivity", Bogor, Indonesia, CIFOR, 2011.

[3] U.J. Siregar, I.Z. Siregar, I. Novita, Keragaman fenotipik dan genetik mahoni (Swietenia macrophylla) di Jawa Tengah dan Jawa Timur, in: Prosiding Seminar Nasional Hasil Penelitian Yang Dibiayai oleh Hibah Kompetitif, Bogor, 2007, pp. 161-164. [In Bahasa Indonesia]

[4] Mashudi, M. Susanto, Darwo, Keragaman dan estimasi parameter genetik bibit mahoni daun lebar (Swietenia macrophylla King.) di Indonesia, Jurnal Penelitian Hutan Tanaman 14(2) (2017) 115-126. [In Bahasa Indonesia]

[5] Mashudi. Pertumbuhan tanaman uji keturunan mahoni daun lebar umur 6 bulan di Trenggalek, Jawa Timur, in: A. Asngat, Suparti, Hariyatmi, et al. (Eds), Seminar Nasional Pendidikan Biologi dan Saintek III, Surakarta, 2018, pp. 194-200. [In Bahasa Indonesia]

[6] BPS Trenggalek, Kecamatan Bendungan Dalam Angka, Trenggalek, 2018. [In Bahasa Indonesia]

[7] E.B. Hardiyanto, Diktat mata kuliah pemuliaan pohon lanjut, Yogyakarta, Fakultas Kehutanan Universitas Gadjah Mada, 2011. [In Bahasa Indonesia]

[8] Mashudi, Keragaman pertumbuhan bibit mahoni daun lebar (Swietenia macrophylla King.) dari dua populasi di Yogyakarta, in: A. Hayati, D. Winarni, H. Purnobasuki, et al. (Eds), In: Prosiding Nasional Biodiversitas VI, Surabaya, Departemen Biologi Fakultas Sains dan Teknologi Universitas Airlangga, 2016, pp. 121-129. [In Bahasa Indonesia]

[9] I. Muslimin, A. Sofyan, E. Suherman, et al., Evalusi awal uji keturunan mahoni (Swietenia macrophylla King) umur 1 tahun di Kemampo, Banyuasin, Sumatera Selatan, In: A.H. Lukman , F. Nurfatriani, N.E. Lelana, et al. (Eds), Prosiding Ekspose Hasil Penelitian, Palembang, Balai Penelitian dan Pengembangan Lingkungan Hidup dan Kehutanan Palembang, 2017, pp. 39-45. 
[10] I. Soerianegara, R.H.M.J. Lemmens, Plant Resources of South East Asia 5, Timber Trees "Mayor Commercial Timbers", Bogor, Prosea, 1994.

[11] Y. Nuraeni, H.S. Nuroniah, Biology and dynamics Hypsipyla robusta (Moore) (Lepidoptera: Pyralidae), in: Southeast Asia Plant Protection Conference, Bogor, Indonesia, IOP Publishing, 2019, pp. 1-9.

[12] F. Howard, M. Merida, Mahogany Shoot Borer, Hypsipyla grandella (Zeller) (Insecta: Lepidoptera: Pyralidae: Phycitinae), Institute of Food and Agricultural Sciences Extention 2005(5) (2019) 1-10.

[13] K.E. Wightman, S.E. Ward, J.P. Haggar, et al., Performance and genetic variation of big-leaf mahogany (Swietenia macrophylla King) in provenance and progeny trials in the Yucatan Peninsula of Mexico, Forest Ecology and Management 255(2) (2008) 346-355.

[14] A. Rohandi, N. Widyani, Pertumbuhan tiga provenans mahoni asal Kostarika, Tekno Hutan Tanaman 3(1) (2010) 7-11. [In Bahasa Indonesia]

[15] E. Escalante, P. Saravia, F. Bravo, Survival and growth of big-leaf mahogany ( Swietenia macrophylla King ) seedlings in two provenance trials in Bolivia, Ecologia en
Bolivia 47(1) (2012) 37-52.

[16] C. Navarro, G. Hernández, Progeny test analysis and population differentiation of mesoamerican mahogany (Swietenia macrophylla), Agronomia Costarricense 28(2) (2004) 37-51.

[17] E. Surmaini, E. Runtunuwu, I. Las, Upaya sektor pertanian dalam menghadapi perubahan iklim, Jurnal Litbang Pertanian (2011) 30: 17. [In Bahasa Indonesia]

[18] H.A. Mashudi, Adinugraha, Pertumbuhan tanaman pulai darat (Alstonia angustiloba Miq.) dari empat populasi pada umur satu tahun di Wonogiri, Jawa Tengah, Jurnal Penelitian Kehutanan Wallacea 3(1) (2014) 75-84. [In Bahasa Indonesia]

[19] Mashudi, L. Baskorowati, Respon provenan dan famili tanaman uji keturunan pulai darat (Alstonia angustiloba) terhadap cekaman kekeringan, Jurnal Penelitian Kehutanan Wallacea 5(1) (2016) 47-59. [In Bahasa Indonesia]

[20] A. Abarquez, D. Bush, J. Ata, et al., Early growth and genetic variation of mahagony (Swietenia macrophylla) in progeny tets planted in northern Mindanao, Philippines, Journal of Tropical Forest Science 27(3) (2015) 314324. 